\title{
PERILAKU KONSUMEN TERHADAP PEMAKAIAN JAMU CAP NYONYA MENEER DI KOTAMADYA BENGKULU
}

\author{
Ermy Wijaya \\ Fakultas Ekonomi Universitas Dehasen Bengkulu
}

\begin{abstract}
ABSTRAK
Ermy Wijaya ; Tujuan dari penelitian ini adalah untuk mengetahui apakah ada hubungan yang signifikan antara variabel perilaku di luar konsumen terhadap tingkat konsumsi Jamu Cap Nyonya Meneer dan apakah ada pengaruh variabel perilaku dalam konsumen terhadap tingkat konsumsi Jamu Cap Nyonya Meneer. Kecamatan Gading Cempaka Kota Bengkulu merupakan daerah penelitian yang dipilih dengan populasi penelitian adalah rumah tangga yang tinggal di Kota Bengkulu. Sampel dilakukan berdasarkan kriteria khusus, yaitu semua rumah tangga tergolong dewasa atau berusia 15 tahun ke atas. Dari populasi tersebut dikelompokkan menjadi lima desa, masing-masing desa terpilih diambil sebagai sampel.

Hasil yang diperoleh dari penelitian ini adalah sebagai berikut: tingkat umur sebagai variabel perilaku berpengaruh terhadap perilaku konsumen terhadap tingkat konsumsi Jamu Cap Nyonya Meneerin sesuai dengan tingkat umur. Dimana, pada usia 15-19 cenderung mengkonsumsi Jamu Cap Nyonya Meneerat minimal satu kali, pada usia 20 - 50 dan di atas cenderung mengkonsumsi Jamu Cap Nyonya Meneer. Dari hasil pengujian menunjukkan hubungan yang signifikan secara statistik antara tingkat pendidikan sebagai variabel perilaku luar terhadap perilaku konsumen Jamu Cap Nyonya Meneer. Tingkat pendapatan variabel perilaku luar rumah memiliki hubungan yang signifikan terhadap perilaku konsumen Jamu Cap Nyonya Meneer.
\end{abstract}

\begin{abstract}
Ermy Wijaya ; The aim of this study is to determine is there any significant relationship between the outside behavior variables of consumers to the consumption rate of Jamu Cap Nyonya Meneer and is there influence of inside behavior variables of consumer to the consumption rate of Jamu Cap Nyonya Meneer. Gading Cempaka Subdistrict Bengkulu City is a research area that is selected with the population of research is the households that live in Bengkulu City. The sample was carried out based on specific criteria, i.e all households classified as mature or aged 15 years and above. From the population were classified into five villages, each village elected were taken as sample.

The result gained from the study was as follows: age level as a variable behavior has influence on consumers' behavior to the consumption rate of Jamu Cap Nyonya Meneerin accordance with the age level. Where, at the age of 15-19 tends to consume Jamu Cap Nyonya Meneerat least once, at the age of 20 - 50 and above tends to consume Jamu Cap Nyonya Meneerincreases. From the test results showed a statistically significant relationship between the levels of education as outside behavior variable to the consumers' behavior of Jamu Cap Nyonya Meneer. The level income ofoutside behavior variables has significant relationships on consumers' behavior of Jamu Cap Nyonya Meneer.
\end{abstract}

Key Words : Consumers' Behavior, Level Of Consumstion.

\section{LATAR BELAKANG}

Pemasar merupakan salah satu kegiatan-kegiatan pokok yang dilalukan oleh perusahaan untuk mempertahankan kelangsungan hidupnya, untuk berkembang dan mendapatkan laba (Swuastha DH, 1985 J.Dengan tujuan tersebut suatu perusahaan atau suatu lembaga dalam usahanya untuk meningkatkan volume penjualannya yaitu barang atau jasa yang dihasilkan, haruslah mempunyai atau harus merencanakan sesuatu sesuatu atau strategi pemasaran yang efektif karna dengan meningkatkan volume penjualan maka tujuan utama dari perusahaaan pun akan tercapai seperti apa yang diharapkan, strategi pemasaran menurut Philip kotler (1983). Keberasilan strategi pemasaran suatu perusahaan ditentukan oleh variabel-variabel bauran pemasaran suatu perusahaan atau marketing mix,dimana variabel-variabel tersebut terdiri dari produk, harga distribusi dan promosi. Variabel-variabel bauran pemasaran tersebut haruslah disesuaikan dan dikoordinasikan, sehingga tercipta kombinasi yang baik. Dengan demikian konsumen akan teransang untuk memilih barng-barang hasil produksinya dalam keputusan pembelian konsumen tersebut.

Selain variabel marketing mix tersebut diatas yang dapat mempengaruhi keinginan membeli suatu produk, terdapat faktor-faktor lain yang mempengruhi konsumen. Menurut Basu Swatha DH, dan 
Hani Handoko (1982), faktor-faktor tersebut terbagi menjadi dua yaitu, faktor dari luar (Kebudayaan dan kebudayaan khusus, Kelas soisial, kelompok sosial dan kelompok referensi, dan keluarga ) dan faktor dari dalam (Motivasi, pengamatan, belajar, keperibadian, konsef diri dan sikap).

Dari jumlah penduduk kecamatan gading cempaka, penduduk berjenis kelamin laki-laki yang digolongkan dewasa berjumlah 25.554 jiwa.Sedangkan penduduk berjenis kelamin perempuan yang digolongkan dewasa berjumlah 24.481 jiwa dan anak-anak sebanyak 49.018 jiwa.

Dalam penelitian ini penulis ingin mengetahui dan berusaha mengkaji seberapa jauhkah pengaruh perilaku konsumen terhadap suatu produk. Dalam hal ini produk yang dimaksud adalah jamu Cap Nyoya Meneer. Adapun variabel-variabel perilaku yang dapat mempengaruhi perilaku pembelinya dibagi atas dua bagian yaitu :

1. Variabel dari luar yaitu: Pendidikan, pendapatan, dan status pekerjaan.

2. Variabel dari dalam yaitu: umur.

Jelasnya akan diteliti apakah ada pengaruh ataukah tidak variabel-variabel tersebut diatas terhadap pemakaian jamu Cap Nyonya Meneer sehingga diketahui apakah yang menjadi penyebab seorang konsumen cenderung untuk memakai hasil produknya, maka perusahaan yang bersangkutan dapat menentukan atau menetapkan kebijaksanaan baruan pemasaran yang baik dan tepat untuk tujuantujuan utamanya.

\section{TINJAUAN PUSTAKA}

Menurut William J. Stanton (1988), definisi dari pemasaran adalah suatu sisten keseluruhan dari kegiatan-kegiatan usaha yang ditujukan untuk merencanakan, menentukan harga, mempromosikan dan mendistribusikan barang atau jasa yang memuaskan kebutuhan baik kepada pembeli yang ada maupun pembeli yang potensial.

Sejalan dengan perubahan lingkungan dari waktu-kewaktu, maka kesadaran akan pentingnya pemasaran akan semakin terasa, hal ini terbukti dengan munculnya berbagai konsep dan falsafah-falsafah dalam keberhasilan. Falsafah itu adalah konsep pemasaran, yang tujuannya menurut Basu Swastha DH dan T. Hani Handoko (1982), dalam memberikan kepuasan terhadap keinginan dan kebutuhan konsumen atau beroritasi kepada konsumen.Jadi konsep ini jelas adalah mendorong suatu perusahaan untuk merumuskan kebutuhan dan kegiatan konsumennya.

Radiousnu (1983 ; 10) menguraikan difinisi dari konsep pemasaran yaitu konsep pemasaran merupakan orientasi managamen yang berangapan bahwa tugas pokok perusahaan adalah menentukan kebutuhan, keinginan dan penilaian dari pasar menjadi sasaran, dan menyesuaikan kegiatan perusahaan dengan sedemikian rupa agar dapat mrnyampaikan kepuasan yang diinginkan pasarnya secara lebih episien dan efektif dari saingan-saingannya.

Keinginan dan kebutuhan konsumen mengalami perubahan-perubahan yang tercermin dalam perubahan-perubahan yang tercermin pada perubahaan perilakunya sesuai dengan perubahanperubahan lingkungan yang dinamis. Oleh karna itu untuk memahami untuk memahami perilaku konsumen, suatu perusahaan memerlukan riset pemasaran, dimana riset ini dapat diketahui siapa dan apa keinginan konsumen terhadap produk yang dihasilnya perusahaan yang bersangkutan.

\section{Faktor-Faktor yang Mempengruhi Perilaku Konsumen}

Perilaku konsumen sangat dipengaruhi oleh berbagai faktor lingkungan dimana ia dibesarkan, artinya bahwa konsumen yang berasal dari lingkungan yang satu akan berbeda dengan yang lain, baik itu mengenai penilaian, kebutuhanm pendapat sikap dan selera. Disadari atau tidak, keinginan untuk memebi dan memakai suatu produk atau jasa sangat dipengaruhi oleh berbagai factor, baik dari luar maupun dari dalam diri manusia. Basu Swuasta DH dan T. Hani Handoko (1982) mengelompokkan faktor-faktor tersebut dalam dua katagori, sebagai berikut:

1. Faktor dari luar (ekstern) : kebudayaan dan kebudayaan khusus, kelas sosial, kelompok sosial kelompok referensi dan keluarga.

2. Faktor dari dalam (intern) : Motivasi, Pengamatan, Belajar, Keperibadian dan Konsep diri dan sikap.

Sedangkan menurut E. Jeremo Mc. Carty (1985) faktor-faktor yang mempengruhi kebutuhan konsumen adalah :

1. Faktor intrapersonal Yaitu Motivasi, Persepsi, belajar sikap pandangan, dan keperibadian.

2. Faktor Interpersonal 
Yaitu kebudayaan, kelas sosial, Kelompok Referensi, dan keluarga.Persepsi diartikan makna yang dipertalikan berdasakan pengalaman dari masa lalu, stimulasi atau rangsangan-rangsangan yang kita terima melalui kelima panca indra (William J. Staton 1988). Informasi yang disampaikan oleh pemasar melalui panca indra manusia akan disaring, ditata dan ditapsirkan secara individual. Oleh sebab itu persepsi seseorang dapat sangat berbeda antara satu individu dengan yang lainnya untuk suatu produk tertentu.Belajar diartikan sebagai perubahan pada perilaku seseorang yang timbul dari pengalaman (Philip Kotler, 2011).

Pengalaman yang baik akan membawa seseorang ke sikap yang positif tentang produk atau jasa yang di hasilkan oleh suatu perusahaan, sedangkan sikap yang buruk akan membawa seseorang kesikap yang negatif yang mungkin sukar atau bahkan tidak akan mungkin merubahnya hanya dengan promosi atau periklanan, sikap pandangan adalah sudut pandangan tetap yang layak tentang suatu objek atau kumpulan dari obyek (E. Jeremo Mc. Carthy, 1985).

Keperibadian adalah pola sipat indifidual yang dapat menentukan, tanggapan untuk bertingkah laku (Drs. Basu Swastha DH dan Drs. Irawan MBA, 1985).Sedangkan menurut koentjoroningrat (1983), Keperibadian adalah Ciri watak yang diperlihatkan secara lahir, konsisten dan konsikuen dalam tingkah lakunya sehingga tampak bahwa individu tersebut memiliki indentitas khusus berbeda dari individu yang lainnya.

Dilain sisi, faktor interpersonal mempunyai pengaruh yanh tidak kalah pentingnya dalam menentukan perilaku beli seseorang konsumen.Faktor tersebut adalah kebudayaan, kelas sosial, kelompok sosial, kelompok referensi dan keluarga.

Kebudayaan adalah kumpulan dari kepercayaan sikap dan cara melakukan sesuatu dari kelompok yang sama dari orang-orang (E. Jeremo Mc. Carthy, 1985).Sedangkan arti kebudayaan menurut Wiliam J. Stanton, 1991 ; 131 adalah sebagai berikut kebudayaan adalah komplek symbol dari barangbarang buatan manusia yang diciptakan oleh masarakat tertentu dan diwariskan dari generasi yang satu kegenerasi yang lain sebagai faktor penentu dan pengatur perilaku anggotanya. Simbol dapat berupa sesuatu yang tidak nyata (Sikap, Kepercayaan, Nilai, bahasa, agama) atau sesuatu yang nyata (peralatan, perumahan, produk, hasil seni)"

Kebudayaan suatu daerah akan berbeda dengan kebudayaan daerah lainnya. Hal ini berarti juga pembelian konsumen didaerah yang satu dengan perilaku pembelian konsumen didaerah yang lainnya, menurut koentjoroningrat (1985) terdiri dari tujuh unsure, yaitu :

1. Bahasa

2. System pengetahuan

3. Organisasi sosial

4. System peralatan hidup dan tekhnologi

5. System mata pencarian hidup

6. System religi

7. Kesenian

Kolas sosial sama dengan lapisan sosial. Adapun yang terjadi treteria dalam menggolongkan masarakat kedalam kelas-kelas tertentu, menurut Basu Swashta dan T. Hani Handoko (1982) Adalalah sebagai berikut :

1. Kekayaan

2. Kekuasaan

3. Kehormatan

4. Ilmu pengetahuan

Sedangkan pengelompokan dibagi manjadi tiga golongan (untuk Negara Indonesia) Yaitu

1. Golongan atas : pengusaha kaya dan pejabat tinggi.

2. Golongan menengah : kariawan instansi pemerintah, pengusaha menungah.

3. Golongan rendah : buruh-buruh pabrik, pegawai rendah tukang becak dan pedagang kecil.

Biasanya pembelian yang dilakukan oleh kelompok masarakat cendrerung berbeda antara satu dengan yang lainnya sesuai dengan kelas sosialnya.Kelompok referensi adalah kelompok orang-orang yang mempengaruhi perilaku, nilai dan sikap seseorang (Wiliam J. Stanton 1988).Sedangkan Philip kother (1991) membagi kelompok referensi ini dalam tiga bagian, sebagai berikut :

1. Kelompok primer, sepert keluarga, teman akrab, tetanga dan teman kerja.

2. Kelompok sekunder, seperti organisasi persaudaraan, perserikatan keahlian.

3. Kelompok apresiasi, yaitu kelompok dimana seseorang bukan merupakan anggotanya.

Kelompok tersebut seperti pahlawan dan olahraga dan bintang film.Dalam masing-masing tersebut biasanya mempunyai pelapor atau pimpinan, yang dapat mempengaruhi perilaku anggota kelompok referensi. Dan dalam kenyataan anjuran- anjuran dari orang lain apalagi orang tersebut sebagai 
pelopor atau pimpinan dalam kelompok akan lebih berpengaruh dari pada iklan yang disampaikan pemasar.

Telah dijelaskan pada latar belakang penelitian bahwa variabel perilaku yang mempengaruhi konsumen terhadap pembelian jamu Cap Nyonya Meneer adalah tingkat pendapatan, tingkat pendidikan, status pekerjaan dan umur responden..Besar kecilnya pendapatan yang ditentukan oleh status pekerjaannya. Semakin penting jenis pekerjaan, maka semakin tinggi pula sosial konsumen tersebut. Jadi jenis pekerjaan dan tingkat pendapatannya, merupakan cermin kelas sosial. Basu Swashta DH dan Irawan $(1985 ; 107)$ dalam bukunya yang berjudul : manajemen pemasaran modern : membagi masyarakat kita kedalam tiga golongan tertentu yaitu : kekayaan, kekuasaan, kehormatan, dan ilmu pengetahuan.

Tingkat pendidikan yang dimiliki seseorang akan mempunyai pengaruh tehadap sikapnya dalam pembelian atau pemakaian suatu produk atau jasa. Pendidikan mencerminkan salah satu unsure kebudayaan yang dimiliki seseorang, pendidikan yang diperoleh ini adalah melalui proses belajar. Proses belajar ini juga dialami dalam bentuk perilakunya demi keperluan hidup, dan hal yang harus dibiasakan sejak dia lahir sampai ia mati.

Koenjoningrat (1983) dalam bukunya antropologi, mengartikan kebudayaan sebagai berikut: "kebudayaan adalah keseluruhan system gagasan, tindakan dan hasil karya manusia dalam rangka kehidupan masyarakat yang dijadikan milik diri manusia dengan belajar ".Dari difinisi itu dijelaskan bahwa hampir seluruh tindakan manusia adalah kebudayaaan, bahkan tindakan yang berdasarkan nalurinya, seperti makan dan minum. Hanya sedikit tindakan yang tidak memerlukan proses belajar, seperti tindakan replek, tindakan luar control dirinya dan sebagainya.

\section{Perilaku Konsumen}

James F. Enggel, et al.( Basu Swuastha DH dab T. Hani Handoko, 1982 ) perilaku konsumen adalah kegiatan-kegiatan individu yasng secara langsung terlibat dalam mendapatkan dan mempergunakan barang-barang atau jasa-jasa, termasuk didalamnya proses pengambilan keputusan pada persiapan penentuan kegiatan tersebut.

Dari definisi diatas dapat diambil dua elemen yang penting , yaitu :

1. Proses pengambilan keputusan

2. Kegiatan fisik

3. Proses pengambilan keputusan merupakan pendekatan dari penyelsaian masalah kegiatan manusia untuk membeli barang atau jasa dalam memenuhi keinginan dan kebutuhan. Setiap setiap manusia akan mengalami proses pengambilan keputusan dalam hal melakukan pembelian itu, namun proses tersebut ada yang dilakukan dan ada yang tidak dilakukan. Sekali lagi disini dituntut peran seorang pemasar yang baik untuk dapat merealisasikan kegiatan pembelian dari konsumen tersebut.

Philip Kotler $(1983 ; 257)$ menggambarkan tahap-tahap dalam proses kegiatan suatu pembelian sebagai berikut :

\begin{tabular}{|c|c|c|c|c|}
\hline $\begin{array}{l}\text { Kebutuhan yang } \\
\text { dirasakan }\end{array}$ & $\begin{array}{l}\text { Pencarian } \\
\text { informasi }\end{array}$ & $\begin{array}{l}\text { Penilaian } \\
\text { perilaku }\end{array}$ & $\begin{array}{l}\text { Keputusan } \\
\text { membeli }\end{array}$ & $\begin{array}{l}\text { Perasaan } \\
\text { setelah membeli }\end{array}$ \\
\hline
\end{tabular}

Gambar 1.Tahapan Proses Pengambilan Keputusan Untuk Membeli

Wiliam j. Stanton (1991). Membagi faktor-faktor yang mempengaruhi perilaku kunsumen dalam dua bagian yaitu :

1. Pengaruh kelompok sosial budaya, Yaitu : kebudayaan kelas sosial kelompok acuan yang kecil dan keluarga.

2. Pengaruh kelompok psikologis. Yaitu : pengalaman belajar, keperebadian, sikap dan keyakinan, konsep diri.

Dibawah ini akan digambarkan secara skematis mengenai faktor-faktor perilaku tersebut :

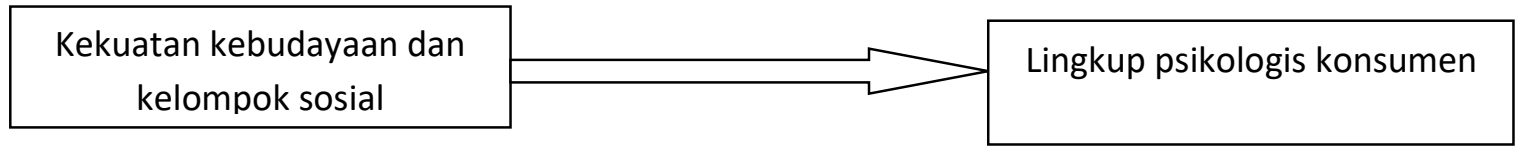

Gambar 2. Kekuatan Sosiobudaya dan Pisikologis yang Mempengaruhi Perilaku Konsumen. 
Dengan berdasarkan akan faktor-faktor tersebut diatas, maka secara tidak langsung perusahaan dapat memilih dan menentukan strategi yang baik dan tepat.Philip Kotler (1991) merumuskan strategi pemasaran.strategi pemasaran adalah suatu proses pengolahan usaha mengembangkan suatu hubungan yang sehat antara oraganisasi dan lingkungannya melalui pengembangan tujuan (propose) sasaran (objective) dan tujuan (goals) strategi pertumuhan dan rencana-rencana port polio usaha perusahaan bagi operasinya sebagai keseluruhan.Sedangkan joseph P. Guiltinan dan Gordon W. Paul (1987) mendefinisikan strategi pemasaran sebagai persatatan pokok tentang dampak yang diharapkan akan dicapai dalam hal permintaan pada pasar target tertentu. Pendekatan terinci untuk menerapkan strategisterategi ini ditentukan lewat program-program pemasatan ayng spesihik, seperti iklan, promosi penjualan, dan salutan distribusi.

Ada tiga macam keputusan yang diambil oleh menejer pemasaran dalam penentuan strategi menurut Basu Swastha DH dan Irawan (1985), Yaitu :

1. Konsumen manakah yang akan ditujuh ?

2. Kepuasan seperti apakah yang di inginkan oleh konsumen ?

3. Bauran pemasaran seperti apakah yang akan dipakai untuk memberikan kepuasan tersebut ?

Suatu perusahaan dapat mengembangkan atau mengkombinasikan variable dari bauran pemasaran tersebut dengan baik, maka dapat dikatakan strategi pemasaranya yang cukup berhasil dimana bauran pemasaran tersebut adalah : Produk, harga Ditribusi dan promosi.

\section{KERANGKA ANALISIS}

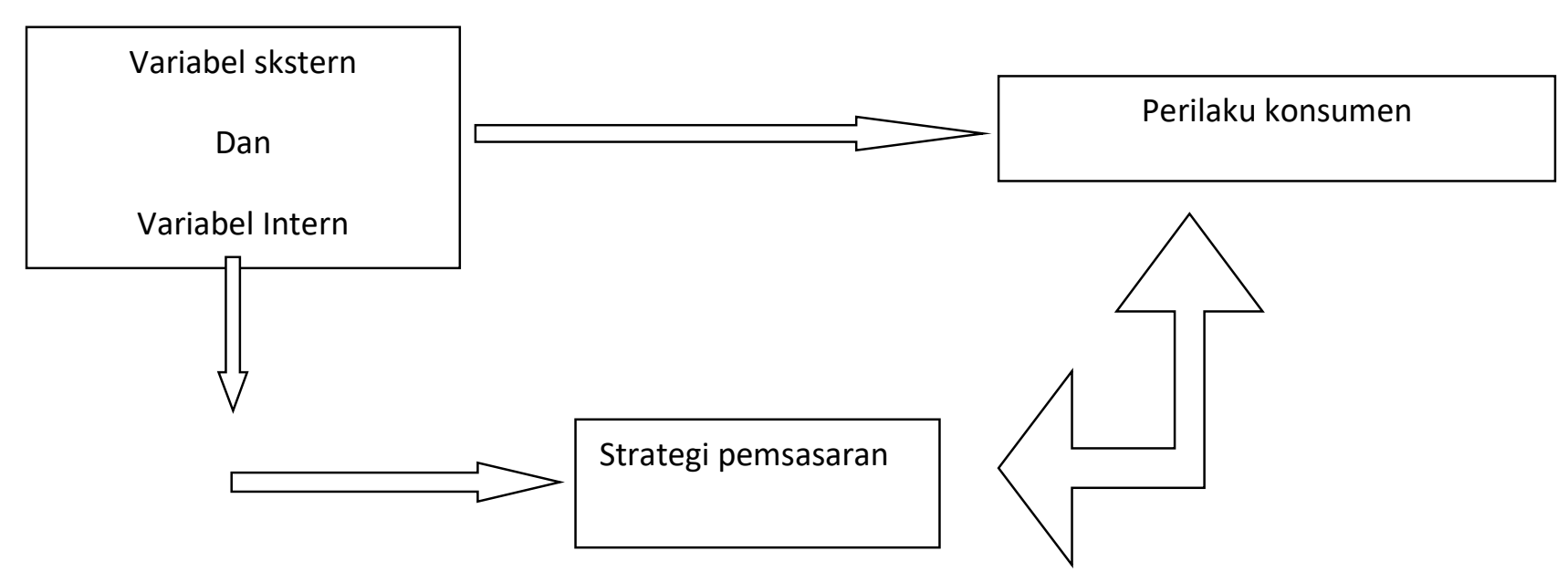

\section{HIPOTESIS}

Dengan berdasarkan latar belakang rumusan masalah yang telah diuraikan, maka hipotesis penelitian ini adalah sebagai berikut :

1. Terhadap hubungan yang signifikan (positif) antara variable perilaku dari luar dengan perilaku konsumen untuk tingkat konsumsi jamu Cap Nyonya Meneer yaitu :

a. Simakin tingggi tingkat pendidikan, maka semakin meningkat kecendrungan konsumen untuk mengkonsumsi jamu Cap Nyonya Meneer. Semakin rendah tingkat pendidikan maka semakin menuntun konsumen yang mengkonsumsi jamu Cap Nyonya Meneer.

b. Semakin tinggi pendapatan, maka semakin meningkat kecendrungan konsumen untuk mengkonsumsi jamu Cap Nyonya Meneer. Semakin rendah pendapatan, semakin menurun konsumen yang mengkonsumsi jamu Cap Nyonya Meneer.

c. Responden yang mempunyai pekerjaan cenderung untuk mengkonsumsi jamu Cap Nyonya Meneeer, sedangkan responden yang ridak mempunyai pekerjaan cenderung tidak mengkonsumsi jamu Cap Nyonya Meneer.

2. Ternyata variabel perilaku dari dalam mempengaruhi perilaku konsumen untuk mengkonsumsi jamu Cap Nyonya Meneer. Semakin mudah umur responden, maka cendrerung untuk mengkonsumsi jamu Cap Nyonya Meneer sedikit sekali. Sedangkan pada usia pertengahan dan tua kecendrungan untuk mengkonsumsi jamu Cap Nyonya Meneer Meningkat.

\section{METODE PENELITIAN}

Dalam penelitian ini penulis mengunakan analis tabulasi silang.Guna tabulasi silang yaitu supaya dalam penyajian data dapat dilihat perbedaaan dari responden yang terpilih sebagai sampel. Untuk 
mengetahui ada tidaknya hubungan yang signihikan antara variabel pengaruh dengan perilaku konsumen terhadap konsumsi jamu Cap Nyonya Meneer, maka digunaka analistis statistik chi square $\left(\mathrm{X}^{2}\right)$. Untuk menguji keeratan hubungan ini terlebih dahulu ditentukan besarnya alpha (a) atau derajat kepercayaan dimana alpha ( a ) yang digunakan adalah sebesar $5 \%$.

\section{METODE ANALISIS}

Dari hasil penelitian langsung yang telah dilakukan, took-toko penjualan jamu yang ada dikotamadya Bengkulu ini dapat digolongkan menjadi tiga jenis yaitu:

1. Toko khusus menjual jamu maksudnya bahwa toko tersebut hanya menjual jamu tanpa menjual produk lainnya.

2. Toko obat dan kosmetik, maksudnya bahwa toko tersebut selain menjual jamu juga menjual obatobatan dan kosmetika.

3. Toko biasa, maksudnya bahwa toko tersebut menjual berbagai macam produk, termasuk juga menjual jamu.

Jumlah pedagang eceran penjualan jamu yang dijadikan sample dalam penelitian didaerah pasar minggu, Jalan A. Yani dan Jalan Soeprapto seluruhnya ada 32 Toko, Jumlah ini meliputi ketiga jenis toko penjualan jamu tersebut. Adapun banyaknya pedagang tersebut dihitung berdasarkan kreteria bahwa toko tersebut adalah toko yang mempunyai nama, tempat yang tepat dengan alamat yang jelas atau dengan kata lain bersifat formal, jadi bukan bersifat non formal, dimana tempat penjualan tidak tentu dan sering berpindah-pindah serta tidak mempunyai nama yang resmi.

\section{Sistem pelayanan}

Pelayanan yang diberikan penjual debagian terbatas pada hubungan penjual dan pembeli saja.Hanya sebagian kecil yang memberikan pelayanan yang baik yang dibutuhkan oleh pembeli. Hal ini dibuktikan dengan adanya pendapat darii responden pada table 1. dibawah ini :

Tabel 1. Pendapat Responden Tetang Pealayanan Penjualan Jamu Dikota Madiya Bengkulu.

\begin{tabular}{|c|c|c|c|}
\hline No & Pelayanan & Jumlah & Presentase \\
\hline 1 & Kurang mengesankan & 10 & 6,67 \\
\hline 2 & Kurang pengetahuan tentang jamu & 30 & 20 \\
\hline 3 & cukup memuaskan & 110 & 73,33 \\
\hline & Jumlah & 150 & 100,00 \\
\hline
\end{tabular}

Sumber : Hasil penelitian

Dari 150 responsen 26, 76 \% mengatakan bahwa pelayanan toko penjualan obat-obatan tradisional jamu dikotamadya Bengkulu ini kurang mengesankan dan pengetahuan dari penjualnanya sangat kurang tentang obat-obatan tradisional itu sendiri.Jumlah toko yang menjual jamu cap Nyonya Meneer

Dari 32 toko ternyata setelah diteliti dan diadakan wawancara hanya 10 diantaranya yang menjual jamu cap Nyonya Meneer. Dari ke 10 pedagang penjual jamu tersebut, 6 terletak dijalan soeprapto, 2 terletak di jalan A. Yani dan 2 Terletak dipasar minggu.

Cara mendapatkan jamu Cap Nyonya Meneer

Sampai penelitian ini dilakukan oleh produsen jamu Cap Nyonya Meneer memasarkan produk langsung ke penjual.Seperti yang dilakukan produsen merk lainnya.

\section{Variasi Produk Jamu Cap Nyonya Meneer yang dijual}

Untuk pedagang eceran jamu dikotamadya Bengkulu 66,66\& (100) responden memakai jamu cap nyonya meneer berpendapat bahwa variasi produk yang dijual cukup memadai. Sedangkan 26, $67 \%(40)$ responden bahwa variasi yang dijual kurang memadai, dimana 6,67 \% (10) responden mengatakan jenis Jamu cap Nyonya Meneer dijual kurang lengkap.

Hasil penelitian tentang perilaku konsumen terhadap tingkat konsumsi jamu cap Nyonya Meneer ternyata 150 responden yang dijadikan sample, tercatat yang 129 responden memberli dan mengkoonsumsi jamu Cap Nyonya Meneer dan 21 tidak membeli ataupun mengkonsumsi jamu cap Nyonya Meneer.Banyaknya alasan mengapa 86 \% (129) dari responden membeli dan mengkonsumsi Jamu Cap Nyonya Meneer, Untuk lebih jelasnya dapat dilihat pada tabel VI. 
Tabel 2. Alasan Yang Mendorang Pemakaian Jamu Cap Nyonya Meneer Menurut Jumlah Responden Pemakai.

\begin{tabular}{|l|c|r|r|}
\hline \multicolumn{1}{|c|}{ Alasan } & Tdk. & \\
\hline Kemasan menarik dan ekslutif & Memakai & Memakai & Jumlah \\
\hline Terdapat bermacam pilihan warna & 12 & 8 & 20 \\
\hline Menarik dan sesuai dengan selera & 18 & 3 & 21 \\
\hline Cocok untuk kesehatan & 40 & 6 & 46 \\
\hline lain-lain & 59 & - & 59 \\
\hline Jumlah & - & 4 & 4 \\
\hline
\end{tabular}

Sumber : Hasil Penelitian

\section{HASIL PENELITIAN DAN PEMBAHASAN}

Penelitian yang terdiri dari karakteristik responden, yang dibagi atas umur, tingat pendidikan, tingkat pendapatan dan jenis pekerjaan.Seanjutnya dikemukakan pula pembuktian hipotesisnya, yaitu tingkat pendidikan, tingkat pendapatan dan stasus pekerjaan, terhadap pemakaian jamu cap nyonya meneer.

\section{Karakteristik responden}

Tujuan dikemukakannya karakteristik ini adalah untuk memperoleh gambar yang ingin diketahui mengenai keadaan dari responden yang diteliti, baik mengenai umur, tingkat pendidikan, tingkat pendapatan, maupun status pekerjaan.Umur Manusia merupakan yang utama dalam suatu pasar.Langkah pertama yang penting untuk mamahami pasar tersebut khususnya pasar konsumen, jumlah penduduk maupun komposisi penduduk menurut umur adalah merupakan Variabel yang perlu diperhatikan. Komposisi umur yang berbeda akan berakibat berbeda pula perilaku pembeli yang dilakukannya, dibawah ini dikemukakan jumlah responden menurut kelompok umur.

Tabel 3. Pemakaian Jamu Cap Nyonya Menner Menurut Redponden Yang Berumur 15 Tahun Keatas (Dewasa) Dikecamatan Gading Cempaka Katamadya Bengkulu.

\begin{tabular}{|l|c|c|c|}
\hline \multicolumn{1}{|c|}{ Kelompok Umur } & Memakai & Tidak Memakai & Jumlah \\
\hline 15-19 Tahun & 7 & 3 & 10 \\
\hline 20-24 Tahun & 10 & - & 10 \\
\hline 25-29 Tahun & 22 & 4 & 26 \\
\hline 30-34 Tahun & 21 & 4 & 25 \\
\hline 35-39 Tahun & 23 & 5 & 28 \\
\hline 40-44 Tahu & 24 & 3 & 27 \\
\hline 45-49 Tahun & 13 & 2 & 15 \\
\hline 50 Tahun Keatas & 9 & - & 9 \\
\hline Jumlah & 129 & 21 & 150 \\
\hline
\end{tabular}

Sumber : Hasil Penelitian

Dari tabel 3. tersebut diatas dapat disimpulkan bahwa pada kelompok umur 15-19 tahun cenderung untuk mengkunsumsi jamu sedikit sekali, baru pada kelompok umur 20-24 tahun sampai sampai kelompok 45-49 tahun dan 50 tahun keatas secara terus menerus mengalami kenaikan.

Berdasarkan banyaknya responden pemakai dari jumlah semua pada masing-masing kelompok umur 20-24 tahun persentase pemakaian adalah sebanyak 16, 66 \% pada kelompok umur 25- 29 tahun menjadi 30 \%, kelompok umur 30-40 tahun sebesar 45,34 \%, kelompok umur 35-39 tahun dan 50 tahun keatas persentase pemakaian meningkat menjadi $54,66 \%$.

Konsumen pada pada kelompok umur 20-39 tahun adalah kelompok yang telah menginjak usia dewasa, pada usia ini biasanya mempunyai pendapatan sendiri, membina karir sendiri, hal tersebut menambah keyakinan pada diri sendiri untuk melakukan sesuatu dengan keinginan ternasuk dalam hal merawat dan menjaga kesehatan diri.

Sedangkan pada kelompok umur 45-49 tahun sampai pada kelompok umur 50 tahun keatas, Kebutuhan akan keamanan dan kesehatan dirasakan menjadi kebutuhan yang sangat penting.Tingkat 
pendidikan yang pernah diiikuti atau ditamati oleh responden di kecamatan gading cempaka kotamadya Bengkulu dapat dilihat pada tabel IX di bawah ini.

Tabel 4.Tingkat Pendidikan Responden Jamu Cap Nyonya Meneer Di kecamatan Gading Cempaka Kota Madya Bengkulu.

\begin{tabular}{|l|c|c|}
\hline \multicolumn{1}{|c|}{ Tingkat Pendidikan } & Jumlah & Presentase \\
\hline Tamat SD & 15 & 10 \\
\hline Tamat SLTP & 27 & 12 \\
\hline Tamat SLTA & 49 & 32,66 \\
\hline Sarjana Muda & 29 & 19,34 \\
\hline Sarjana & 30 & 20 \\
\hline Jumlah & 150 & 100 \\
\hline
\end{tabular}

Sumber : Hasil Penelitian

Secata garis besar dapat dikatakan bahwa pada umumnya tingkat pendidikan yang pernah ditamati oleh penduduk kecamatan gading cempaka Kotamadya Bengkulu, Rata-rata tamatan SLTA. Dari tabel 4. diatas ternyata sebagaian besar yaitu 32,66 \% memiliki tingkat pendidikan tamatan SLTA, Jadi lebih dari jumlah responden, sedangkan responden yang tamat SD $10 \%$, SLTP $12 \%$, Sarjana Muda 19,34 $\%$ dan Sarjana $20 \%$.

Tingkat Pendapatan, Untuk dapat berbelanja sesuatu diperlukan uang, dan uang tersebut diperoleh dari hasil pendapatan. Jadi dapat dikatakan bahwa pendapatan adalah factor yang paling penting dalam pemenuhan keinginan dan kebutuhan seseorang di zaman sekarang ini.Tanpa pendapatan atau uang tidak mungkin keinginan dan kebutuhan tersebut dapat dipenuhi dengan mudah.

\section{PEMBUKTIAN HIPOTESIS}

Setelah karakteristik responden diketahui maka dapat dibuktikan hipotesis yang telah dikemukakan melalui uji CHI square, yaitu hubungan tingkat pendidikan dengan tingkat konsumsi jamu Cap Nyonya Meneer, Hubungan tingkat pendapatan dan tingkat konsumsi Jamu Cap Nyonya Meneer dan Status pekerjaan dengan tingkat konsumsi jamu Cap Nyonya Meneer.

Hubungan Tingkat pendidikan dengan tingkat konsumsi jamu cap nyonya meneer.

Menurut ahli-ahli fsikologi, perkembangan manusia ditentukan oleh faktor pembawaan dan bakat serta pengalaman dan pengaruh lingkungan.Pengetahuan atau informasi-informasi yang telah diperoleh seseotang dari kedua faktor tersebut dapat mempengruhi tingkat kecerdasan dan pola berpikirnya.Dari lingkungan dimana salah satunya melalui jenjang kependidikan, seseotang mendapatkan bimbingan dan latihan yang lebih sempurna dan sistematis. Hal ini secara tidak langsung akan mempertajam daya tengkap terhadap sesuantu pilihan produk mana yang paling baik baginya, sehingga dapat memuaskan keinginan dan kebutuhan secara maksimal.Untuk melihat apakah ada hubungan yang signifikan antara tingkat pendidikan an konsumsi jamu Cap Nyonya Meneer dapai dilihat pada tabel 5.

Tabel 5. Hubungan Tingkat Pendidikan Dengan Ringkat Konsumsi Jamu Cap Nyonya Meneer Dikecamatan Gading Cempaka Kotamadya Bengkulu.

\begin{tabular}{|l|c|c|c|c|}
\hline \multicolumn{1}{|c|}{ Biaya Pemakaian } & Rupiah/BI & Rupiah/BI & Rupiah/BI & \multirow{2}{*}{ Jumlah } \\
\hline Tingkat Pendidikan & $0-25$ & $25-40$ & $>40$ & \multirow{2}{*}{15} \\
\hline Tamatan SD & 8 & 4 & 2 & 27 \\
\hline & $(53,3)$ & $(33,3)$ & $(13,4)$ & \\
\hline Tamatan SLTP & 10 & 12 & 5 & 29 \\
\hline & $(37,0)$ & $(44,4)$ & $(18,6)$ & \\
\hline Tamatan SLTA & 14 & 19 & 16 & 29 \\
\hline & 28,6 & $(38,7)$ & 32,7 & \\
\hline Sarjana Muda & 4 & 15 & 10 & 20 \\
\hline & $(13,8)$ & $(51,7)$ & $(34,5)$ & 150 \\
\hline Sarjana & 5 & 17 & 18 & 100 \\
\hline
\end{tabular}

Sumber : Hasil Penelitian

$\mathrm{X}^{2}$ Hitung $=17,50$ 
$\mathrm{X}^{2}$ Alpha 0,$05 ; \mathrm{db} .8+15,507$

$\mathrm{C}=0,32$

C Maksimum $=0,86$

Data tabel 5, diatas memperlihatkan bahwa nilai hitung pada DF=8 dan Alpha 0.05 atau interval kepercayaan 95\% adalah lebih besar dibandingkan dengan $\mathrm{X}^{2}$ tabel $\left(\mathrm{X}^{2}\right.$ tabel $=15.507$ dan $\mathrm{X}^{2}$ hitung $=$ 17.50). berarti dari perbandingan itu jelas bahwa $X^{2}$ lebih besar dari $X^{2}$ tabel dan hal ini membuktikan kebenaran hipotesis yaitu terdapat hubungan yang siknifikan antara tingkat pendidikan dengan tingkat konsumsi jamu cap Nyonya Menner.

Salah satu variable yang dapat mempengaruhi permintaan suatu produk adalah tingkat pendapatan.Pendapatan pada umumnya berbentuk uang yang diterima oleh seseorang sebagai hasil usaha yang telah dilakukannya.Semakin besar uang yang ada padanya semakin besar pula kecendrungan untuk membelanjakannya, maka semakin kecil kecendrungan untuk membelanjakan uang tersebut.Apakah ada hubungan yang siknifikan antara tingkat penmdapataan terhadap tinghkat konsumsi, khususnya untuk produk jamu cap Nyonya Menner, dapat kita lihat pada tabel 6.

Tabel 6. Hubungan Antara Tingkat Pendapataan Dengan Tingkat Biaya Konsumsi Jamu Cap Nyonya Menner Di Kecamatan Gading Cempaka.

\begin{tabular}{|c|c|c|c|c|}
\hline $\begin{array}{c}\text { Biaya } \\
\text { Pemakaian(000) } \\
\end{array}$ & $0-25$ & $>25-40$ & $>40$ & Jumlah \\
\hline $\begin{array}{l}\text { Tingkat } \\
\text { Pendapatan }\end{array}$ & Rp/Bulan & Rp/Bulan & Rp/Bulan & $(\%)$ \\
\hline \multirow[t]{2}{*}{$0-100$} & 9 & 6 & 2 & 17 \\
\hline & $(7,64)$ & $(7,14)$ & $(5,21)$ & $(100)$ \\
\hline \multirow[t]{2}{*}{$100-150$} & 7 & 10 & 4 & 21 \\
\hline & $(5,74)$ & $(8,82)$ & $(6,64)$ & $(100)$ \\
\hline \multirow[t]{2}{*}{$150-200$} & 11 & 19 & 13 & 43 \\
\hline & $(11,75)$ & $(, 18,06)$ & $(13,18)$ & $(100)$ \\
\hline \multirow[t]{2}{*}{$200-250$} & 8 & 12 & 14 & 43 \\
\hline & $(9,29)$ & $(14,28)$ & $(10,43)$ & $(100)$ \\
\hline \multirow[t]{2}{*}{$250-300$} & 4 & 10 & 11 & 25 \\
\hline & $(6,83)$ & $(10,5)$ & $(7,66)$ & $(100)$ \\
\hline \multirow[t]{2}{*}{ 300-keatas } & 2 & 6 & 2 & 10 \\
\hline & $(2,73)$ & 4,2 & $(3,07)$ & $(100)$ \\
\hline $\mathrm{N}$ & 41 & 63 & 46 & 150 \\
\hline Prosentase & $(27,3)$ & $(42)$ & $(30,7)$ & $(100)$ \\
\hline \multicolumn{5}{|l|}{$\mathrm{X}^{2}$ Hitung $=19,622$} \\
\hline \multicolumn{5}{|c|}{$\mathrm{X}^{2}$ Alpha $0,05:$ db. $10=18,307$} \\
\hline
\end{tabular}

Sumber : Hasil Penelitian

Data tabel 6 diatas memperlihatkan bahwa nilai hitung pada $\mathrm{df}=\mathrm{dan}$ alpha $=0,05$ adalah lebih besar dibandingkan dengan $\mathrm{X}^{2}$ Tabel $\left(\mathrm{X}^{2}=18,307\right.$ dan $\mathrm{X}^{2}$ Hitung $\left.=19,622\right)$ hal ini berarti bahwa hipotesa yang mengatakan adanya hubungan yang signifikan antara tingkat pendapatan dengan tingkat konsumsi dapat diterima, jadi semakin tinggi tingkat pendapatan, maka semakin tinggi pula kecendrungan untuk mengkonsumsi jamu cap Nyonya Meneer dan sebaliknya.

Sedangkan hubungan kedua varibel tersebut diatasnya dinyatakan cukup erat yang membuktikan dengan membandingkan $\mathrm{C}$ dengan $\mathrm{C}$ maksimum, Di mana $\mathrm{C}=0,34$ dan Maksimum $=0,816$.

Hubungan jenis dan status pekerjaan dengan tingkat konsumsi jamu Cap Nyonya Meneer di kecamatan Gading cempaka Kotamadya Bengkulu.Untuk menentukan apakah ada hubungan yang signifikan antara status pekerjaan dengan tingkat konsumsi jamu cap Nyonya Meneer dapat dilihat pada tabel 7. 
Tabel 7. Hubungan Jenis Dan Status Pekerjaan Dengan Tingkat Biaya Konsumsi Jamu Cap Nyonya Meneer Kecamatan Gading Cempaka Kotamadya Bengkulu.

\begin{tabular}{|l|c|c|c|c|}
\hline \multicolumn{1}{|c|}{$\begin{array}{c}\text { Biaya } \\
\text { Pemakaian(000) }\end{array}$} & $0-25$ & $>25-40$ & $>40$ & Jumlah \\
\hline Status Pekerjaan & $\mathrm{Rp} /$ Bulan & $\mathrm{Rp} /$ Bulan & Rp/Bulan & $(\%)$ \\
\hline Bekerja & 30 & 59 & 44 & 133 \\
\hline & $(36,35)$ & $(55,86)$ & $(40,78)$ & $(100)$ \\
\hline Tidak Bekerja & 41 & 4 & 2 & 17 \\
\hline $\mathrm{N}$ & $(4,64)$ & $(42)$ & $(5,21)$ & $(100)$ \\
\hline Prosentase & 41 & 63 & 46 & 150 \\
\hline $\mathrm{X}^{2}$ Hitung $=14,206$ & $(27,3)$ & $(42)$ & $(30,7)$ & $(100)$ \\
\hline $\mathrm{X}^{2}$ Alpha $0,05:$ db. $2=5,991$ & & & \\
\hline $\mathrm{C}=0,34$ dan C Maksimal $=0,71$ & & & \\
\hline
\end{tabular}

Sumber : Hasil Penelitian

Dara tabel 7. diatas menujukkan bahwa responden yang bekerja lebih banyak mengkonsumsi jamu cap Nyonya jamu Cap Nyonya Meneer jika dibandingkan dengan responden yang tidak bekerja. Hal ini dapat dilihat bahwa hubungan antara status pekerjaan dengan tingkat biaya konsumsi ini juga ditunjang dengan hasil penelitian yang menunjukkan bahwa X2 hitung = 14,206 > X2 Alpha 0,05; db. $2=$ 5,991 , jadi jelas bahwa ada hubungan yang sigihikan antara jenis dan status pekerjaan dengan konsumsi jamu Cap Nyonya Meneer.

Sedangkan besar $\mathrm{C}=0,294 \mathrm{C}$ maksimum $=0,71$. Perbandingan ini membuktikan bahwa hubungan kedua variable cukup erat.

\section{KESIMPULAN}

1. Tingkat umur sebgai variabel perilaku dalam diri seseorang ternyata mempengaruhi pemakaian jamu cap Nyonya Meneer sesuai dengan tingka umurnya. Pada tingkat umur 15- 19 tahun cenderung mengkonsumsi sedikit sekali dan dari hasil penelitian hanya 8,66 \% dari jumlah responden pada tingkat umur tersebut yang mengkonsumsi jamu Cap Nyonya Meneer. Pada tingkat umur 20 - 50 tahun keatas cenderung konsumsi meningkat. Hal ini ditunjukan dengan hasil presentase pemakaian pada masing-masing kelompok umur.

2. Tingkat pendidikan yang perna diikuti mempunyai hubungan yang signatifikan terhadap keinginan untuk mengkonsumsi jamu cap nyonya Meneer,dimana nilai $\mathrm{X}^{2}$ hitung lebih besar dari $\mathrm{X}^{2}$ tabel $(17,50>15,507)$ dan hubungan tersebut cukup erat yang ditunjukkan dengan nilai $\mathrm{C}=0,32$ Dan nilai C Maksimum = 0, 816 .

3. Demikian juga hubungan antara tingkat pendapatan keluarga dengan tingkat konsumsi Jamu cap Nyonya Meneer mempunyai hubungan yang signifikan atau pengaruh yang positif, dimana $\mathrm{X}^{2}$ hitung lebih besar dari $\mathrm{X}^{2}$ tabel $(19,622)>18$, 307) serta nilai $\mathrm{C}=0,34$ dan Nilai $\mathrm{C}$ Maksimum 0,816 menunjukkan bahwa hubungan tersebut cukup erat.

4. Status pekerjaan juga mempunyai hubungan yang signifikan terhadap konsumsi jamu Cap Nyonya Meneer hal ini ditunjukan dengan nilai $\mathrm{X}^{2}$ hitung yang jauh lebih besar dari nilai $\mathrm{X}^{2}$ tabel, Yaitu $14,206>5,991$. Kemudian dari perbandiangan antara nilai C dan Nilai C Maksimum hubungan tersebut sangat kuat, yaitu $C=0,29$ DAN C Maksimum =0,71.

\section{SARAN}

1. Sekalipun telah dibuktikan dalam penelitian ini, bahwa baik variasi dari luar maupun dari dalam diri seseorang mempunyai pengaruh yang positif terhadap keinginan seseorang untuk mengkonsumsi jamu Cap Nyonya Meneer namun factor-faktor lainnya juga harus diperhatikan seperti strategi bauran pemasaran (marketing mix) yang dijalankan baik oleh produsen yang bersangkutan maupun oleh perentara-perentara penjualan agar tujuan yang diinginkan dapat tercapai.

2. Dari haril penelitian ternyata pengaruh variabel perilaku dalam mengkonsumsi Jampu Cap Nyonya Meneer yang paling dominan adalah status pekerjaan, dimana persponden yang bekerja cenderung untuk mengkonsumsi Jamu Cap Nyonya Meneer.

3. Dengan berdasarkan penemuan bahwa status pekerjaan mempunyai pengaruh yang paling besar dirumah tangga merupakan sasaran pemasaran yang paling baik, oleh karna itu dapat berhasil, perusahaan yang bersangkutan harus lebih aktif untuk menentukan strategi pemasaran. 


\section{DAFTAR PUSTAKA}

Basu Swastha DH. Dan Hani Handoko, 1982. Manajemen Pemasaran : Analisa Perilaku Konsumen. Yogyakarta, Liberty.

Basu Swatha DH. Dan Irawan, 1985. Manajemen pemasaran modern.Yogyakarta Libery.

Clindiff, Edwar W. 1988. Dasar-dasar marketing. Yogyakarya Liberty.

Djarwanto Ps. Dan Pangestu Subagya, 1990.Statistik Indukatif. Yogyakarta, BPFE.

Dayan, Anto. 1974, Pengantar metode Statistik Jilid II, Jakarta LP3ES.

Guiltinan, Josep. Dan Paul Gorden W. 1987. Strategi dan Programmanajemen pemasaran, Jakarta , Erlangga.

Koentjoninrat, 1983.Pengantar ilmu antropologi, Jakarta, Aksara Baru.

Kotler, Philip, 1988, Manajemen Pemasaran :Analisa Perencanaan Implementasi dan pengendalian, Jakarta, Erlangga.

Mc. Carthy, Jerome E. 1985. dasar-dasar pemasaran Jakarta, Erlangga.

Panglaykim, et al. 1987.Marketing, Jakarta, Universitas Terbuka.

Radiosunu, 1983. Manajemen Pemasaran : Suatu Pendekantan Analisis, Yogyakarta, BPFE.

Sudjana, 1988.Statistika. Bandung, Tarsito.

Sekaran, 2006. Research Method for Business.Metologi Penelitian II Bisnis, Salemba Empat.Jakarta

Stanton, Wiliam J. 2001. Prinsip Pemasaran, Jakarta, Erlangga.

Sutrisno Hadi. 1987. Metode Research, Yogyakarta, Yayasan Penerbit Faktultas Fisikologi Universitas Gaja Mada.

Supranto.J.2001, Pengukuran Tingkat Kepuasan Pelanggan, Jakarta:PT.Rineka Cipta

Tjiptono,Fandy (2006),Pemasaran Jasa, Edisi 2.Malang: Bayumedia Publising

Zeitharml.V.A 1990.Delivering Service Quality: Balancing Custumer Perception and Expectations. New York: The Free Press. 